\title{
Comparative genomic analysis of Tropheryma whipplei strains reveals that diversity among clinical isolates is mainly related to the WiSP proteins
}

\author{
My-Van La ${ }^{1}$, Nicolas Crapoulet ${ }^{1}$, Pascal Barbry ${ }^{2,3}$, Didier Raoult ${ }^{1}$ and \\ Patricia Renesto*1
}

Address: ${ }^{1}$ Unité des Rickettsies, CNRS-UMR6020, IFR48, Faculté de Médecine, 27 Bd Jean Moulin, Marseille, F13385, France, ${ }^{2}$ CNRS, Institut de Pharmacologie Moléculaire et Cellulaire, UMR6097, Sophia Antipolis, F06560, France and ${ }^{3}$ Université de Nice Sophia Antipolis, Institut de Pharmacologie Moléculaire et Cellulaire, UMR6097, Sophia Antipolis, F06560, France

Email: My-Van La - my-van.la@medecine.univ-mrs.fr; Nicolas Crapoulet - crapsnico@yahoo.fr; Pascal Barbry - barbry@ipmc.cnrs.fr; Didier Raoult - Didier.Raoult@medecine.univ-mrs.fr; Patricia Renesto* - patricia.renesto@medecine.univ-mrs.fr

* Corresponding author

Published: 2 October 2007

BMC Genomics 2007, 8:349 doi:10.1 |86/|47|-2164-8-349
Received: 12 April 2007

Accepted: 2 October 2007

This article is available from: http://www.biomedcentral.com/I47I-2164/8/349

(C) 2007 La et al.; licensee BioMed Central Ltd.

This is an Open Access article distributed under the terms of the Creative Commons Attribution License (http://creativecommons.org/licenses/by/2.0), which permits unrestricted use, distribution, and reproduction in any medium, provided the original work is properly cited.

\begin{abstract}
Background: The aim of this study was to analyze the genomic diversity of several Tropheryma whipplei strains by microarray-based comparative genomic hybridization. Fifteen clinical isolates originating from biopsy samples recovered from different countries were compared with the $T$. whipplei Twist strain. For each isolate, the genes were defined as either present or absent/divergent using the GACK analysis software. Genomic changes were then further characterized by PCR and sequencing.

Results: The results revealed a limited genetic variation among the $T$. whipplei isolates, with at most $2.24 \%$ of the probes exhibiting differential hybridization against the Twist strain. The main variation was found in genes encoding the WiSP membrane protein family. This work also demonstrated a $19.2 \mathrm{~kb}$-pair deletion within the T. whipplei DIGI5 strain. This deletion occurs in the same region as the previously described large genomic rearrangement between Twist and TW08/27. Thus, this can be considered as a major hot-spot for intra-specific $T$. whipplei differentiation. Analysis of this deleted region confirmed the role of WND domains in generating $T$. whipplei diversity.

Conclusion: This work provides the first comprehensive genomic comparison of several $T$. whipplei isolates. It reveals that clinical isolates originating from various geographic and biological sources exhibit a high conservation rate, indicating that $T$. whipplei rarely interacts with exogenous DNA. Remarkably, frequent inter-strain variations were dicovered that affected members of the WiSP family.
\end{abstract}

\section{Background}

Tropheryma whipplei is a Gram positive bacterium responsible for Whipple's disease [1]. This chronic, multisystemic infection is mainly characterized by intestinal malabsorption, but also involves other organs such as the heart and central nervous system and is ultimately fatal without appropriate treatment [2]. T. whipplei infection in human beings is particularly interesting due to the wide 
range of disease outcomes [3]. While it is known to be associated with the environment $[4,5]$, the natural reservoir of T. whipplei is still unknown.

In 2000, the first human isolate of this bacterium was successfully cultured in a fibroblast cell line [6]. This allowed investigators to examine the phenotypic characteristics of the bacterium, about which little had been known $[1,7]$, and made possible the sequencing of the $0.93 \mathrm{Mb}$ genome $[8,9]$. This major achievement has provided new perspectives on both the diagnosis and treatment of Whipple's disease $[10,11]$. Among the first post-genomic applications was the successful design of a comprehensive culture medium, based on computer modeling of metabolic networks, which allowed the axenic growth of the microorganism [12]. The use of the axenic culture medium for diagnostic purposes has enabled isolation of several $T$. whipplei strains from cerebrospinal fluid, blood, synovial fluid, lymph node, cardiac valve, skeletal muscle, and stool [3]. T. whipplei replication in the absence of eukaryotic cells has also facilitated the immunoproteomic analysis of this pathogen, which was conducted using sera from patients [13]. Finally, the absence of eukaryotic nucleic acids favored optimization of RNA extraction [14], thus making microarray-based transcriptional studies possible $[15,16]$.

The DNA microarrays allow for the identification of changes in gene expression in response to specific stimuli from the environment on a global scale. This technology also provides a powerful tool to study genome variability among strains. Thus, microarray-based comparative genomic hybridization (CGH) was described as a good alternative to whole genome sequencing [17], and has been applied for several human pathogens [18]. Such an approach was shown to be useful to assess genome plasticity and evolutionary trends including analysis of potential gene transfer events [19]. Moreover, CGH analysis was found to be helpful in revealing gene polymorphisms associated with distinct tissue tropisms or niche adaptation [20-22], in characterizing virulence factors [23-28] and in providing putative vaccine candidate antigens $[23,29]$.

To date, two T. whipplei strains have been sequenced, TW08/27 [9] and Twist [8]. These strains were isolated from cerebrospinal fluid collected in Germany [9] and the cardiac valve of a Canadian patient [6], respectively. A comparative analysis of the two strains revealed a large chromosomal inversion. This observation, associated with a high nucleotide identity between both strains (> $99 \%$ ), was considered to be an indication of a very active genome rearrangement process [8]. Such genomic recombination was hypothesized to be mediated by the WND protein-coding repeats within genes encoding the WiSP membrane proteins and to be associated with changes in the set of proteins exposed at the surface of the bacteria. According to this perspective, recombination would constitute an adaptive response to the host defense or to environmental conditions.

Due to the variable pathological profiles which can result from T. whipplei infection, we hypothesized that it could be of interest to further define the genetic diversity of various strains. To obtain information on T. whipplei gene content, we performed a comparative analysis of sixteen clinical isolates by CGH using the whole $T$. whipplei Twist strain cDNA microarray. Results were subsequently validated by PCR and sequencing.

\section{Results \\ Accuracy of genomic DNA hybridization on T. whipplei microarray}

Screening for divergent or absent regions in T. whipplei strains isolated in our laboratory was carried out using a microarray chip containing PCR products from 804 genes corresponding to $99.5 \%$ of the T. whipplei Twist genome [15]. In the first step, the accuracy of the T. whipplei genomic DNA hybridization assays was determined through control experiments self-hybridizing Cy5-labeled Twist with Cy3-labeled Twist. As expected, the corresponding GACK analysis, which allows coding sequence (CDS) classification as either conserved or absent/divergent using a trinary output under stringent conditions [30], showed that $100 \%$ of the CDSs were present. No hybridization was observed against negative control DNAs present on the microarrays. Accordingly, we concluded that both experimental and computational processing were appropriate for analyzing our data.

\section{Global analysis of conserved and divergent CDSs in the T. whipplei genome}

Given the estimated probability of CDS presence deduced from the GACK analysis of the 45 hybridization profiles obtained, it appeared that T. whipplei genomic sequences were highly conserved across the 16 isolates tested (Table 1). These 45 hybridizations consisted of three repeats of the hybridization of 15 distinct $T$. whipplei isolates $v$ s. the Twist strain. Comparative analysis showed that relative to the Twist isolate, the percentage of conserved CDSs ranges from $97.76 \%$ (strain Dig15) to 99.88\% (strains Slow1B, Neuro1, and DigNeuro14). The heat map visualization of genomic variations showed that there were differences spread across the entire genomes (Additional file 1). Only 34 genes from the Twist isolate were predicted to be absent or highly divergent in at least one tested strain. Reduced hybridization can result either from whole gene deletion or from nucleotide sequence variation. In order to clarify the nature of the observed deletion/divergence, PCR were performed using specific primers located 
Table I: T. whipplei isolates used in this study and percentage of conserved CDSs identified through CGH analysis

\begin{tabular}{|c|c|c|c|c|c|}
\hline Isolate designation & Sample origin & $\begin{array}{l}\text { Clinical } \\
\text { manifestations }\end{array}$ & Patient (sex, age) & $\begin{array}{l}\text { Geographical } \\
\text { origin }\end{array}$ & $\%$ conserved CDSs \\
\hline Twist & Aortic valve & EW & M42 & Canada & 100.00 \\
\hline Endo 5 & Heparinized blood & EW & M6I & France & 99.63 \\
\hline Endo 7 & Aortic valve & EW & M67 & Portugal & 99.75 \\
\hline Slow IB & Faeces & $\begin{array}{l}\text { CWD, digestive } \\
\text { relapse }\end{array}$ & F34 & France & 99.88 \\
\hline Slow 2 & Duodenal biopsy & CWD & F70 & France & 99.50 \\
\hline ART I & Synovial fluid & CWD & M68 & France & 99.13 \\
\hline Neuro I & Cerebrospinal fluid & $\begin{array}{l}\text { CWD, neurologic } \\
\text { relapse }\end{array}$ & M57 & Germany & 99.88 \\
\hline Neuro 2 & Cerebrospinal fluid & $\begin{array}{l}\text { CWD with neurologic } \\
\text { involvement }\end{array}$ & F40 & France & 99.63 \\
\hline Dig 7 & Heparinized blood & CWD & M64 & France & 99.00 \\
\hline Dig 9 & Heparinized blood & CWD & M35 & France & 99.38 \\
\hline Dig 10 & Cerebrospinal fluid & $\begin{array}{l}\text { CWD with neurologic } \\
\text { involvement }\end{array}$ & M46 & Germany & 99.63 \\
\hline Dig ADP II & $\begin{array}{l}\text { Mesenteric lymph } \\
\text { node }\end{array}$ & CWD & M56 & France & 99.50 \\
\hline Dig Neuro 14 & Cerebrospinal fluid & $\begin{array}{l}\text { CWD with neurologic } \\
\text { involvement }\end{array}$ & M50 & Germany & 99.88 \\
\hline Dig 15 & Cerebrospinal fluid & $\begin{array}{l}\text { CWD with neurologic } \\
\text { involvement }\end{array}$ & $M 60$ & Germany & 97.76 \\
\hline Dig Musc 17 & Muscle & CWD & F73 & France & 99.25 \\
\hline Dig Neuro 18 & Cerebrospinal fluid & $\begin{array}{l}\text { CWD with neurologic } \\
\text { involvement }\end{array}$ & M68 & France & 99.25 \\
\hline
\end{tabular}

upstream and downstream of the targeted CDSs. The electrophoresis migration profile obtained for TWT596 is shown in Figure 1. Analysis of the 72 deletions/divergences showed a reduced PCR amplicon size consistent with the gene deletion observed in the 27 cases (Table 2). Sequencing of the PCR products with the same migration profile as those obtained from the T. whipplei Twist strain indicated that the lower hybridization resulted from a sequence variation in $43 / 45$ genes. Further analysis of nucleotide changes resulted in the identification of one silent mutation (TWT176 in Dig15 strain). The genes were interrupted by STOP codons in 9 cases, and 3 of these were related to TWT099, which encodes a protein of unknown function. The observed sequence divergences mainly induce amino acid changes. Interestingly, when a gene exhibited variations in several strains, the amino acid changes they trigger were found to be partly conserved (Figure 2 and Additional file 2). In two cases of genes encoding proteins of unknown function, TWT151 and TWT722, the predicted deletion/divergence was not associated with nucleotide changes. These false-positive values were not included in the dendrogram established from the overall CGH assay including sequencing data. As shown in Figure 3, Dig7, Dig9, Slow2, Endo5, Endo7, Art1 and DigMus 17 formed a group distinct from Neuro2, DigADP11, Neuro1, DigNeuro18, Dig10, DigNeuro14,
Slow1B; and Twist. Dig15 appeared to be phylogenically distinct from all other isolates.

\section{Major genomic changes are related to genes encoding for WiSP family proteins}

The distribution of the 34 absent/divergent CDSs was analyzed according to their functional classification. Of these, 23 genes encoded hypothetical proteins. This corresponds to $10 \%$ of unknown genes annotated in the T. whipplei Twist genome. The functional category exhibiting the most number of genes altered, including both deletions and mutations, corresponds to membrane proteins. Thus, $4 / 15$ proteins $(26.7 \%)$ in the WiSP family were found to be absent or divergent. While most of the genes (58.9\%) exhibited divergence in only 1 of the 16 examined strains, more frequent changes were observed in the WiSP family proteins (Table 2). TWT232 and TWT594 sequence variations were observed in 3 and 9 T. whipplei strains, respectively, while TWT596 was found to be absent in 6 strains and divergent in another one. With the exception of Slow1B, DigNeuro14 and Neuro2 strains, the WiSP proteins differed from Twist in all T. whipplei strains. Other CDS variations shared by several T. whipplei strains encode either hypothetical proteins ( 9 cases), membrane proteins (1 case), or FtsE, a cell division ATP-binding protein 

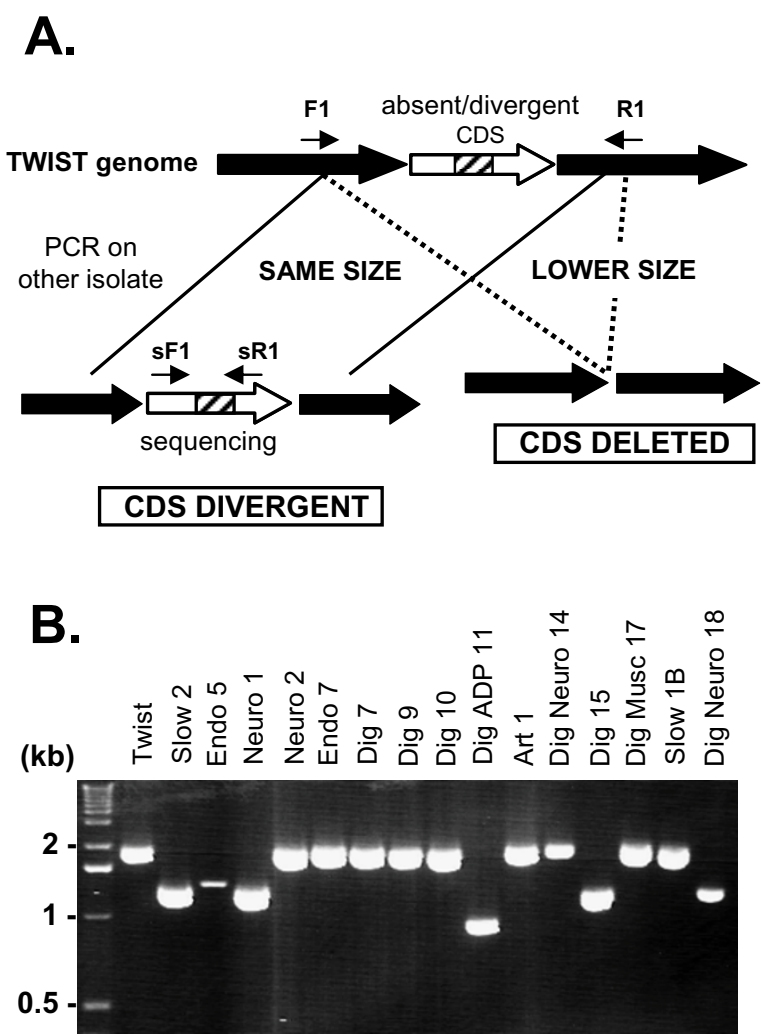

Figure I

(A) Schematic representation of PCR and sequencebased strategies used to further investigate genomic deletion or divergence. Two couples of primers were designed based on the genome sequence of $T$. whipplei Twist strain, including one (FI/RI) flanking the gene predicted absent/divergent by $\mathrm{CGH}$ analysis, and another (sFI/sRI) flanking the PCR amplicon spotted on the microarray represented by the hatched square. (B) PCR analysis of a putative TWT596 deletion on various $T$. whipplei strains. The amplicon size obtained using the primers TWT595F I and TWT597RI and T. whipplei Twist DNA as positive control was of $2040 \mathrm{nt}$. Lower size amplicons were obtained with Slow2, Endo5, Neurol, DigADPI I, DigI 5 and DigNeurol 8, indicating that the gene was deleted in these strains. The first lane corresponds to DNA size standard (I kb DNA ladder, Invitrogen).

(which had nucleotide changes in the Dig7, DigADP11, Art1, DigMusc17, and DigNeuro18 strains).

\section{CGH analysis reveals a major deletion in $\mathrm{T}$. whipplei DIGI5}

A more detailed analysis was then performed on the genomic region of $T$. whipplei DIG15 strain ranging from TWT608 to TWT624. Several genes consecutively located in this region were predicted to be absent/divergent in this strain, and other genes were characterized as uncertain (Table 3). PCR assays were thus designed to bridge each of the putatively deleted regions. A 2,950 bp amplicon was amplified using forward and reverse primers located on TWT607 and TWT625, and further sequenced to determine the exact location of the deletion event (Additional file 3). These data demonstrated that all 17 CDSs located between TWT607 and TWT625 were absent in T. whipplei DIG15. Half of these corresponded to proteins with unknown functions (Table 3). Genes encoding previously characterized proteins such as recA and ftsK were also absent. The GC\% value of this deleted region was $46.59 \%$, compared to $46.3 \%$ for the whole genome [8]. Interestingly, the boundaries of this deleted genomic region are two genes that belong to the WiSP membrane protein family, namely TWT608 and TWT624. The sizes of these genes in the T. whipplei Twist strain are 1,044 and 2,070 nucleotides, respectively. Both genes share an $\mathrm{N}$-terminal WND domain that could trigger a recombination event. From BLAST analysis, both genes were found to be $99 \%$ identical over a 784 bp nucleotide fragment. In the DIG15 sequenced amplicon, the region without BLAST similarities to TWT607, TWT625 or their adjacent intergenic spacer is only 563 nucleotides. This indicates that the recombination event induced a deletion around $19 \mathrm{~kb}$ within the WND domain-containing WiSP proteins. This deletion was also observed by PCR in the primary isolate stored after the first passage in the fibrosblast cell line (not shown). This putative recombination event is shown in Figure 4.

\section{Discussion}

One of the major results from the CGH analysis performed with a microarray composed of PCR products amplified from the $0.93 \mathrm{Mb}$ T. whipplei Twist genome [15], is the remarkable preservation of the genomic content of the 16 T. whipplei isolates. As previously claimed $[31,32]$, one of the limitations of this technique is the failure to detect genes that were not spotted on the microarrays. However, the high genomic conservation rate observed in this study is consistent with the fact that $T$. whipplei gene family size is an ancestral feature. This suggests an evolutionary scenario where the isolates originating from diverse sources have all evolved from a common ancestor.

The percentage of T. whipplei Twist probes exhibiting differential hybridization in other strains is in the same range as those described for the Francisella tularensis [33], Chlamydia trachomatis [22], Coxiella burnetii [28], and Rickettsia prowazekii species [24]. A common trait among these pathogens and T. whipplei is a small genome size between 0.93-2.0 Mb, a marked AT nucleotide bias, and the loss of several metabolic pathways, which explains their complex nutritional requirements [8,34-37]. While F. tularensis can 
Table 2: PCR and sequencing confirmation of CDSs identified as absent/divergent by CGH analysis

\begin{tabular}{|c|c|c|c|c|c|c|}
\hline \multirow[b]{2}{*}{ Gene ID } & \multirow[b]{2}{*}{ Gene name } & \multirow[b]{2}{*}{ Gene product } & \multirow[b]{2}{*}{$\begin{array}{c}\text { Intensity of } \\
\text { Hybridization } \\
\text { lower than with } \\
\text { Twist }\end{array}$} & \multicolumn{3}{|c|}{ PCR and sequencing } \\
\hline & & & & Genes deleted & $\begin{array}{l}\text { Genes with nt } \\
\text { variation(s) }\end{array}$ & $\begin{array}{c}\text { Genes } \\
\text { conserved }\end{array}$ \\
\hline TWT0I8 & $\operatorname{deo} D$ & $\begin{array}{l}\text { purine nucleoside } \\
\text { phosphorylase }\end{array}$ & I & & I & \\
\hline TWT04I & - & hypothetical protein & 7 & 7 & & \\
\hline TWT099 & - & hypothetical protein & 3 & & 3 & \\
\hline TWTIOI & - & hypothetical protein & 1 & 1 & & \\
\hline TWTI5I & - & hypothetical protein & i & & & I \\
\hline TWTI58 & - & hypothetical protein & 3 & 3 & & \\
\hline TWTI7I & - & hypothetical protein & 2 & & 2 & \\
\hline TWTI76 & - & hypothetical protein & 1 & & 1 & \\
\hline TWTI99 & ftsE & $\begin{array}{l}\text { cell division ATP-binding } \\
\text { protein }\end{array}$ & 5 & & 5 & \\
\hline TWT203 & $k s g A$ & dimethyladenosine transferase & 1 & & I & \\
\hline TWT232 & - & WiSP family protein & 3 & & 3 & \\
\hline TWT277 & - & hypothetical protein & 1 & & 1 & \\
\hline TWT3II & - & hypothetical protein & 1 & & I & \\
\hline TWT386 & $\operatorname{trp} E$ & $\begin{array}{l}\text { anthranilate synthase } \\
\text { component I }\end{array}$ & 1 & & I & \\
\hline TWT388 & - & hypothetical protein & 2 & & 2 & \\
\hline TWT594 & - & WiSP family protein & 9 & & 9 & \\
\hline TWT596 & - & WiSP family protein & 7 & 6 & I & \\
\hline TWT604 & - & hypothetical protein & 2 & 1 & 1 & \\
\hline TWT6I3 & - & hypothetical protein & 1 & I & & \\
\hline TWT6I4 & ftsK & cell division protein FtsK & i & I & & \\
\hline TWT6I5 & - & hypothetical protein & 1 & 1 & & \\
\hline TWT6I7 & - & hypothetical protein & 1 & I & & \\
\hline TWT618 & wblE & $\begin{array}{l}\text { Putative transcription reg. } \\
\text { protein }\end{array}$ & 1 & 1 & & \\
\hline TWT619 & - & hypothetical protein & 1 & 1 & & \\
\hline TWT62I & - & hypothetical protein & 1 & 1 & & \\
\hline TWT624 & - & $\begin{array}{l}\text { WND-containing WiSP } \\
\text { family protein }\end{array}$ & 1 & 1 & & \\
\hline TWT653 & - & membrane protein & 2 & I & I & \\
\hline TWT673 & - & hypothetical protein & 1 & & 1 & \\
\hline TWT679 & - & hypothetical protein & 3 & & 3 & \\
\hline TWT704 & - & hypothetical protein & 2 & & 2 & \\
\hline TWT722 & - & hypothetical protein & I & & & 1 \\
\hline TWT75I & - & hypothetical protein & I & & I & \\
\hline TWT762 & - & hypothetical protein & 2 & & 2 & \\
\hline \multirow[t]{2}{*}{ TWT773 } & - & hypothetical protein & 1 & & I & \\
\hline & & TOTAL & $72(100 \%)$ & 27 (37.50\%) & 43 (59.70\%) & $2(2.80 \%)$ \\
\hline
\end{tabular}

The values correspond to the number of strains for which mentioned parameters were found different to that observed in $T$. whipplei Twist. (nt): nucleotide.

replicate under axenic conditions in vitro, it is thought that obligate host-dependent survival is required in its natural life cycle [37]. The strictly intracellular niche of T. whipplei is still under debate. However, the high level of similarity between $T$. whipplei strains strongly suggests that these microorganisms are mainly associated with host cells in vivo. While free-living and facultative intracellular bacteria might be constantly bombarded with foreign genes, genetic exchange opportunities are limited for obligate intracellular bacteria, which may result in few evolutionary events of gene transfer [38,39]. In contrast to what was observed for T. whipplei and other host-associated pathogens, the CGH analysis performed on enteric bacteria including Salmonella enterica [40], Campylobacter jejuni [41], Helicobacter pylori [42], Shigella [27,31] or Enterococcus faecalis [43] evidenced 15 to $23 \%$ genetic variations. 


\begin{abstract}
TWT171: unknown
Twist RMHWPVDACWPGIKLFWINWSLLVFSAILLWYAFSACRKVGRVVAYIGSIGGGALLSLRTLLAHPSYTPHL

Dig7 RMHWPVDACWPGIKLFRTNWSLLVFSAILLWYAFSACRKVCHVVAY IGS IGGGALLSLRTLLAHPSYTPHL

Dig15 RMYG 15 DACWPGIKLFWT-NWSLLVFSAILLWYAFSACRKVGHVVAYIGS IGGGALLSLRTLLAHPSYTPHL

TWT232: WiSP

TWist AVGVFSNGAGPTTPVVVVHPNNRTTVCLTCICNRAVIRLRPKCIGEPVKHILSSX

Dig9 AVGVFSNGADSTTPVVVVPPNNRTTICLTCICNRTVIRLRPKCIGEPVKHILSSX

Art1 AVGVFSNGADSTTPVVVVPPNNRTTICLTCICNRTVIRLRPKCIGEPVKHILSSX

DigMUSC17 AVGVFSNGADSTTPVVVVPPNNRTTIECLTCICNRTVIRLRPKCIGEPVKHILSSX

TWT679: unknown

Twist KPLSRGIKIGASVVALCVSVLLIAIFSLMTRPIGNDYHTTSFKVKSDNEVIVEFSFTGHIPTVCAVRVLGRDMSTVGWKVVPVLSPHMEVGLRTTKVAX Dig7 KPLSRGIKIGASVVAICVSVLLIGIFSLMTRPIGNDYHTTSFKVKSDNEVIVGFSFTGHIPTVCAVRVLGHDMSTVGWKVVPVLSPHMEVGLRTTKVAX Art1 KPLSRGIKIGASVVAICVSVLLIGIFSLMTRPIGNDYHTTSFKVKSDNEVIVGFSFTGH IPTVCAVRVLGHDMSTVGWKVVPVLSPHMEVGLRTTKVAX

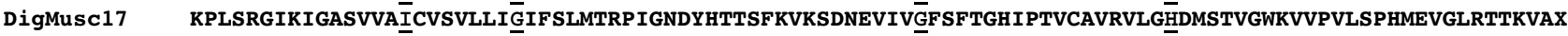

\title{
Figure 2
}

Alignment of partial protein sequences from several T. whipplei isolates. Divergent amino acids relative to T. whipplei Twist strain were underlined and written in bold characters.

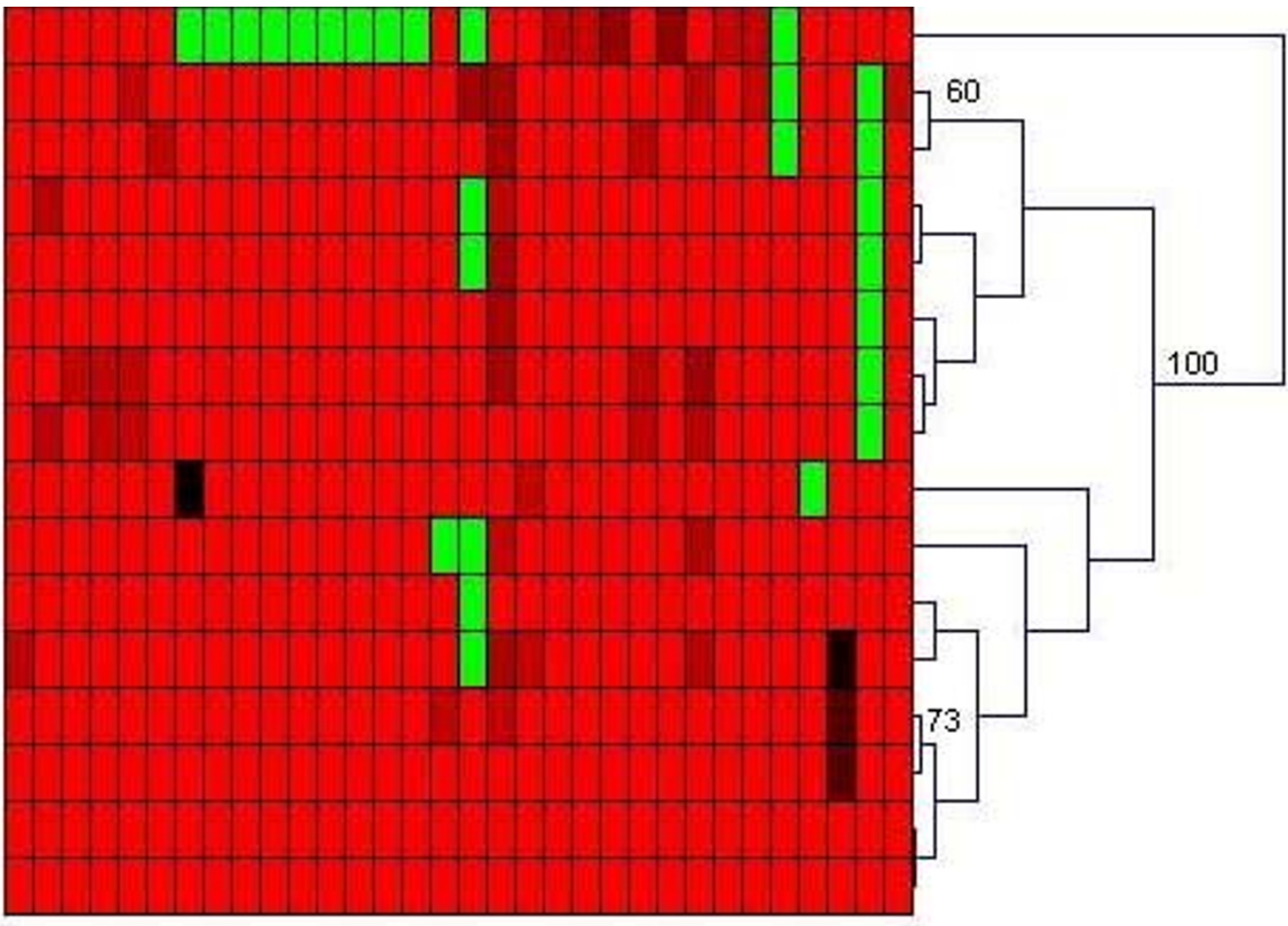

Neuro2

DigADP11

Neuro1

DigNeuro18

Dig10

DigNeuro14

Slow1B

Twist

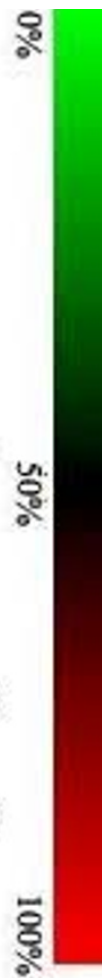

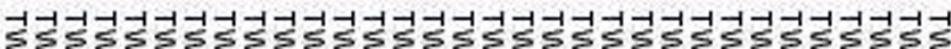

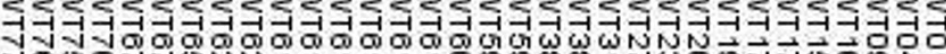

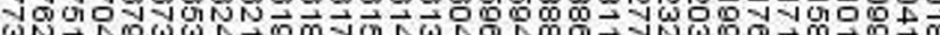

Figure 3

Phylogenic relationships of T. whipplei isolates based on CGH data. CGH data were analyzed using TIGR Multiexperiment Viewer $(\mathrm{MeV})$ [5I]. Statistical analysis of each node of the tree was determined by bootstrap analysis with I,000 replicates using the clustering support tree. Only bootstrap values greater than 50 are indicated. In the color scheme at the top of the figure, the brightest green corresponds to CDSs that are absent and brightest red indicates CDSs that are absent. The graduate scale corresponds to the percent of homologies of sequenced genes with Twist genes. 
Table 3: List of genes deleted in DIGI5

\begin{tabular}{|c|c|c|c|}
\hline Gene ID & Gene name & CGH & Sequencing \\
\hline TWT607 & WiSP family protein & +1 & present \\
\hline TWT608 & WND-domain containing, WiSP family protein & 0 & deleted \\
\hline TWT609 & miaA; tRNA isopentenylpyrophosphate transferase & 0 & deleted \\
\hline TWT6I0 & hypothetical protein & 0 & deleted \\
\hline TWT6II & recA; recombinase $\mathrm{A}$ & 0 & deleted \\
\hline TWT6I2 & pgsA; CDP-diacylglycerol - glycerol-3-phosphate 3-phosphatidyltransferase & 0 & deleted \\
\hline TWT6I3 & hypothetical protein & -1 & deleted \\
\hline TWT6I4 & ftsK; cell division protein FtsK & -1 & deleted \\
\hline TWT6I5 & hypothetical protein & -1 & deleted \\
\hline TWT6I6 & thy $X$; thymidylate synthase & 0 & deleted \\
\hline TWT6I7 & hypothetical protein & -1 & deleted \\
\hline TWT6I8 & wblE; putative transcription regulatory protein & -1 & deleted \\
\hline TWT619 & ORFan & -1 & deleted \\
\hline TWT620 & hypothetical protein & 0 & deleted \\
\hline TWT62I & hypothetical protein & -1 & deleted \\
\hline TWT622 & rph; ribonuclease $\mathrm{PH}$ & 0 & deleted \\
\hline TWT623 & hypothetical protein & 0 & deleted \\
\hline TWT624 & WND-domain containing, WiSP family protein & -1 & deleted \\
\hline TWT625 & putative serine protease & +1 & present \\
\hline
\end{tabular}

$(+1)$ : present; (0): uncertain; (-I): absent

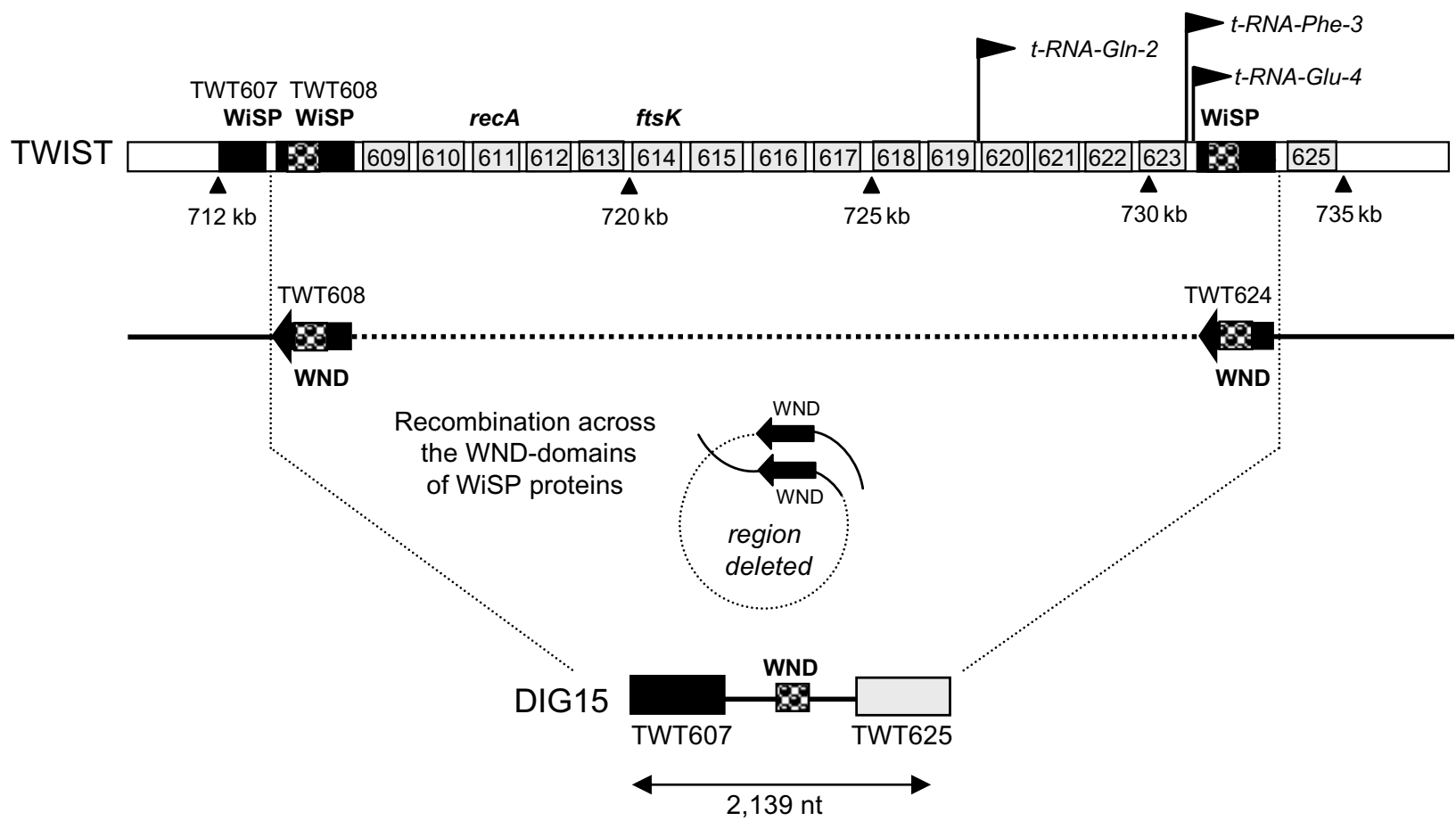

Figure 4

Schematic representation of the genomic rearrangement observed in DIGI5. Two WND repeats (Accession number: PF0786I) were found in the genes TWT608 and TWT624 that are respectively located at both extremities of the $19.3 \mathrm{~kb}$ region of the Twist strain deleted in DIGI5. 
Among the 34 lacking or divergent CDSs found in at least one of the tested strains, 23 encode for proteins of unknown function, which can be considered non-essential for bacterial survival and replication. This is mainly the case for TWT041 and TWT099-encoded proteins, which are deleted and interrupted, respectively, in several T. whipplei strains. While strain-specific divergences were shown for deoD (Dig7), ksgA (Dig15), and $\operatorname{trpE}$ (Dig15), nucleotide changes in $f t s E$ were observed in $31.25 \%$ of isolates. These modifications lead to amino acid changes in 4 isolates, the gene being interrupted in the fifth one. Alignment of the whole ftsE Twist gene [8] with the TW08/ 27 gene [9] showed $70 \%$ similarity, which is in disagreement with the $99 \%$ identity of both genomes at the nucleotide sequence level [8]. Recent evidence showed that FtsE was absolutely required for the process of bacterial division in low osmotic strength conditions, because this protein ensures the stability of the septal ring assembly [44]. In contrast, this $\mathrm{ABC}$ transporter-type protein was described as non-essential for bacteria grown under highosmolarity conditions, as shown by viable ftsE null mutants $[44,45]$. Relationships between mutations within the Aeromonas hydrophila ftsE gene and the filamentous phenotype of the bacteria, which likely interferes with opsonophagocytosis, were also observed [46]. These authors hypothesized that the formation of large bacterial aggregates that could not be ingested by phagocytic cells could be used to evade the immune system. The relevance of FtsE changes for each T. whipplei strains is questionable, but it can be hypothesized that the protein plays a role in adaptating to environmental change.

This CGH analysis showed that the WiSP proteins, heterogeneous surface proteins grouped into a family based on several identifying features including WND repeats [9], are highly divergent across the T. whipplei strains compared in this study. A high divergence rate of genes related to surface structure proteins has been described for several pathogens including Yersinia pestis [21], Campylobacter jejuni [41], and Shigella [31]. The heterogeneity of the T. whipplei WiSP proteins is consistent with observations made in previous studies using a shotgun sequence assembly of the T. whipplei strain TW08/27 [9]. Indeed, these authors provided evidence for the existence of 44 loci located within the WiSP coding sequence TW570, where variations that mainly resulted in single amino acid changes were observed. PCR amplification and sequencing of the N-terminal region of this gene further revealed variations when the same culture was collected at different passages [9]. Comparing different isolates showed that TWT594 and TWT596, which are partly homologous to the TW570 gene of T. whipplei TW08/27 strain, either exhibited several amino acid mutations or were lacking. Amino acid changes were observed in the WiSP protein encoded by TWT594 in 8 isolates, and a frame-shift muta- tion was found in another strain. Deletion of the gene encoding the TWT596 WiSP protein was observed in $43 \%$ of the strains analyzed. While $4.2 \%$ of the T. whipplei CDSs appeared to have diverged in the Twist strain relative to the other 15 strains tested, this value increased to $26.7 \%$ when genes that belong to the WiSP protein family were considered. These data emphasize the diversity of such membrane proteins across various strains. Altogether, these findings suggest that divergent evolution of this select set of genes could be associated with development of bacteria which have similar genomic contents, in different environments. WiSP proteins exhibit amino acid hypervariation that could be responsible for various pathological features and immune system evasion.

There was a notable deletion of 17 CDSs corresponding to $19,052 \mathrm{~kb}$ in the T. whipplei DIG15 strain, ranging from TWT608 to TWT624. PCR amplification carried out on the primary isolate of DIG15 concluded that this evolutionary event did not occur in vitro. As previously reported for the chromosomal inversion seen in the T. whipplei Twist and TW08/27 strains [8], this deletion event is associated with flanking WiSP membrane protein family coding genes. This fits well with the proposed role of the conserved Nterminal WND domain in these proteins, with respect to promoting genome recombination [8]. The observed deletion probably results from homologous recombination events across such conserved domains. A correlation between the hypermutable regions of the F. tularensis genome and the presence of repeated sequences has been previously reported [33]. The majority of deleted genes in the T. whipplei DIG15 strain encode proteins with unknown function that can be considered as non-essential. DNA rearrangements are believed to contribute to the fitness of a pathogen in specific environments. Thus, the adaptation of bacterial pathogens from the Bartonella and Rickettsia genera, to host-restricted vectors such as lice, was associated with accelerated rates of genome degradation [47]. Interestingly, both major genomic rearrangements, such as the chromosomal inversion among Twist and TW08/27 and the $19 \mathrm{~kb}$ deletion in DIG15, are located in the same region which can be considered as the major hot-spot for intra-strain differentiation in T. whipplei.

\section{Conclusion}

In summary, this work provides the first comprehensive genomic comparison of several isolates of $T$. whipplei. It reveals that clinical isolates originating from various geographic and biological sources exhibit a high conservation rate, suggesting that $T$. whipplei rarely interacts with exogenous DNA. The frequent variations among members of the WiSP membrane protein family is a remarkable trait. The significance of these changes remains to be investigated. 


\section{Methods}

T. whipplei isolates and preparation of genomic DNA

T. whipplei isolates $(\mathrm{n}=16)$ used in this study are detailed in Table 1. These strains correspond to the whole collection of $T$. whipplei isolates available in our laboratory when the project was initiated. Of the available strains, 3/ 16 were isolated from patients with endocarditis, which is representative of Whipple's disease patients worldwide [3]. None of the patients were related to each other or had been in contact. All bacterial isolates used in this study were grown under axenic conditions as previously described [12]. Eighteen day-old bacterial cultures (300 $\mathrm{ml}$ ) were collected by centrifugation $16,900 \times \mathrm{g}$ for $10 \mathrm{~min}$ at $4{ }^{\circ} \mathrm{C}$. The resulting pellets were resuspended in $3 \mathrm{ml}$ PBS and stored at $-20 \mathrm{C}$. DNA was extracted using the QIAamp ${ }^{\circledast}$ DNA mini kit according to the manufacturer's instructions (Qiagen, Courtaboeuf, France), and the DNA concentration was determined by UV absorbance at 260 $\mathrm{nm}$.

\section{Genomic DNA labeling}

In the microarray experiments described below, DNA from the T. whipplei Twist strain was used as a reference, whereas the DNA from other isolates was referred as test DNA. DNA was labeled with Cy3-dCTP and Cy5-dCTP (Amersham Biosciences, Piscataway, NJ, USA) for the test and reference samples, respectively, using the BioPrime ${ }^{\circledR}$ Array CGH Genomic Labeling System (Invitrogen, Carlsbad, CA, USA). For each hybridization, $1 \mu \mathrm{g}$ of $T$. whipplei Twist DNA and test DNA were primed with random octamers, and Cy3- or Cy5-labeled probes were generated under the extension and fluorescent nucleotide incorporation activity of exo-Klenow polymerase. The levels of incorporation were quantified by absorbance measurement at $550 \mathrm{~nm}$ and $650 \mathrm{~nm}$. Samples were processed for hybridization on microarrays when the incorporation levels were $\geq 50 \mathrm{pmol}$ of fluorochromes per $\mu \mathrm{g}$ of DNA.

\section{Microarray hybridization}

This study used T. whipplei microarrays spotted with 804 DNA fragments amplified from the Twist strain by PCR [15]. These 804 amplicons corresponded to $99.5 \%$ of annotated CDSs from the T. whipplei Twist genome. These microarrays also included DNA sequences from yeast intergenic regions (Lucidea ${ }^{\mathrm{TM}}$ Universal Score Card $^{\mathrm{TM}}$, Amersham) that were used as negative controls. Following a post-processing step, $7 \mu \mathrm{g}$ of labeled DNA for each reference and test sample were pooled for hybridization onto microarrays as previously described [15]. All experiments were conducted in triplicate, yielding 12 independent measurements for each condition (representing 4 technical and 3 biological replicates). After an 18-hour incubation at $42^{\circ} \mathrm{C}$, the slides were washed, dried with compressed nitrogen, and scanned with the ScanArray ${ }^{\circledR}$ Express (Perkin Elmer, Boston, MA, USA).

\section{Microarray data analysis}

The signal intensity, local background for both fluorescence channels of each spot, and the preliminary exclusion of irrelevant values, as flagged, were determined from TIF images using the QuantArray ${ }^{\circledR}$ Microarray Analysis Software version 3.0.0.0 (Packard BioScience). Data filtering and normalization were then performed using the Microsoft Excel software. Spots with background-corrected signal intensity (median) less than two-fold of the background intensity (median) in both channels were excluded from further analysis. The background-subtracted signals derived from the remaining spots were normalized by the global median method, and the normalized log ratio of test/reference signal for each spot was recorded. For each CDS and each comparative strain analysis, the median value of 12 normalized log ratios of the test/reference signal was used for GACK analysis [30]. Trinary output was then applied to determine if the CDS was present, uncertain, absent, or divergent. When the deduced estimated probability of presence (EPP) was $100 \%$, genes were designated as present (assigned ' +1 '). Genes with 0\% EPP were assigned into absent/divergent category ('-1'). The lack of hybridization to a probe spot can indeed result from the absence of the gene or it can be due to divergence of the gene within a portion of the gene including the probe. When the EPP values ranged between $0 \%$ and $100 \%$, the presence or absence/divergence of the gene remained uncertain. GACK calculates dynamic cutoff values and can generate improved identification of absent/divergent genes independently of any normalization process that would be strongly influenced by differences between the reference strain and tested strains. In our case, because the number of absent/divergent genes is very small, the global median method of normalization is reasonable.

\section{$P C R$ verification and sequence analysis}

To validate the results predicted by CGH, all deletion/ divergence events were verified by PCR amplification and/ or subsequent sequencing. For every gene suspected to be absent/divergent, one pair of primers was designed to anneal to the upstream and downstream genes flanking the target region. The reaction was performed with DNA from each strain using the Expand High Fidelity PCR (Roche, Penzberg, Germany) according to the manufacturer's protocol. All PCR products were examined using $1 \%$ agarose gels and stained with ethidium bromide. When the size of the PCR amplicons was similar to that obtained with T. whipplei Twist, the putative divergence in nucleotide sequences was assessed through sequencing (ABI PRISM ${ }^{\circledast}$ BigDye $^{\circledR}$ Terminator v1.1 Cycle Sequencing Kit, Applied Biosystems, Foster City, CA, USA). Obtained sequences were compared to that of the T. whipplei Twist strain by the CLUSTALW program [48]. All primers used in this study are listed in Additional file 4. 


\section{Phylogenetic analysis}

A numerical score was assigned to each CDS analyzed based on the following criteria: +3 for present, -3 for absent, and +1 for containing nucleotide variation. A dendrogram was constructed using hierarchical clustering with Euclidean distance by Genesis software version 1.7.2 [49].

\section{Accession numbers}

All CGH results are available in the GEO database [50] under accession number GSE7453. Nucleotide sequences correspond to GenBank accession numbers from [GenBank:EF536098] to [GenBank:EF536142].

\section{Authors' contributions}

NC and MVL carried out T. whipplei culture, DNA extraction, and microarray hybridization. MVL also performed comparative genomic analysis and sequencing and participated in drafting the manuscript. PB contributed to DNA microarray construction. DR proposed the research goal and provided critical review of the manuscript. PR supervised the design and the coordination of the entire study and wrote the main draft of the manuscript. All authors read and approved the final manuscript.

\section{Additional material}

\section{Additional file 1}

Genome composition of $16 \mathrm{~T}$. whipplei isolates based on CGH microarray data. This heat map was constructed from the GACK analysis results. Each row corresponds to a specific gene in Twist gene order, whereas columns represent strains analyzed. The CDSs status is color-coded: red, unchanged; green, absent/divergent; black uncertain. The grey lines correspond to missing values.

Click here for file

[http://www.biomedcentral.com/content/supplementary/1471-

2164-8-349-S1.pdf]

\section{Additional file 2}

Alignment of protein sequences from $\mathrm{T}$. whipplei isolates analyzed in this study.

Click here for file

[http://www.biomedcentral.com/content/supplementary/14712164-8-349-S2.pdf]

\section{Additional file 3}

Nucleotide sequences of the genomic region amplified in $\mathrm{T}$. whipplei DIG15 with primers TWT607F1 and TWT625R1.

Click here for file

[http://www.biomedcentral.com/content/supplementary/14712164-8-349-S3.pdf]

\section{Additional file 4}

Oligonucleotide primers used for PCR and sequencing.

Click here for file

[http://www.biomedcentral.com/content/supplementary/14712164-8-349-S4.pdf]

\section{Acknowledgements}

The authors wish to acknowledge the contribution of Quentin Leroy for data analysis and dendrogram construction. This work was achieved with the excellent support of the Nice-Sophia Antipolis Transcriptome Platform of the Marseille-Nice Genopole, where the microarrays were constructed.

\section{References}

I. La Scola B, Fenollar F, Fournier PE, Altwegg M, Mallet MN, Raoult D: Description of Tropheryma whipplei gen. nov., sp. nov., the Whipple's disease bacillus. Int J Syst Evol Microbiol 2001, 5I:|47|- |479.

2. Marth T, Raoult D: Whipple's disease. Lancet 2003, 36 I:239-246.

3. Fenollar F, Puechal X, Raoult D: Whipple's disease. N Engl J Med 2007, 356:55-66.

4. Maiwald M, Schuhmacher F, Ditton HJ, von HA: Environmental occurrence of the Whipple's disease bacterium (Tropheryma whippelii). Appl Environ Microbiol 1998, 64:760-762.

5. Schoniger-Hekele M, Petermann D, Weber B, Muller C: Tropheryma whipplei in the Environment: Survey of Sewage Plant Influxes and Sewage Plant Workers. Appl Environ Microbiol 2007, 73:2033-2035.

6. Raoult D, Birg ML, La SB, Fournier PE, Enea M, Lepidi H, Roux V, Piette JC, Vandenesch F, Vital-Durand D, Marrie TJ: Cultivation of the bacillus of Whipple's disease. N Engl J Med 2000, 342:620-625.

7. Lepidi H, Fenollar F, Gerolami R, Mege JL, Bonzi MF, Chappuis M, Sahel J, Raoult D: Whipple's disease: immunospecific and quantitative immunohistochemical study of intestinal biopsy specimens. Hum Pathol 2003, 34:589-596.

8. Raoult D, Ogata H, Audic S, Robert C, Suhre K, Drancourt M, Claverie JM: Tropheryma whipplei Twist: a human pathogenic Actinobacteria with a reduced genome. Genome Res 2003, 13:1800-1809.

9. Bentley SD, Maiwald M, Murphy LD, Pallen MJ, Yeats CA, Dover LG Norbertczak HT, Besra GS, Quail MA, Harris DE, von HA, Goble A, Rutter S, Squares R, Squares S, Barrell BG, Parkhill J, Relman DA: Sequencing and analysis of the genome of the Whipple's disease bacterium Tropheryma whipplei. Lancet 2003, $361: 637-644$

10. Masselot F, Boulos A, Maurin M, Rolain JM, Raoult D: Molecular evaluation of antibiotic susceptibility: Tropheryma whipplei paradigm. Antimicrob Agents Chemother 2003, 47:1658-1664.

II. Fenollar F, Fournier PE, Robert C, Raoult D: Use of genome selected repeated sequences increases the sensitivity of PCR detection of Tropheryma whipplei. J Clin Microbiol 2004, 42:40I-403.

12. Renesto P, Crapoulet N, Ogata H, La SB, Vestris G, Claverie JM, Raoult D: Genome-based design of a cell-free culture medium for Tropheryma whipplei. Lancet 2003, 362:447-449.

13. Kowalczewska M, Fenollar F, Lafitte D, Raoult D: Identification of candidate antigen in Whipple's disease using a serological proteomic approach. Proteomics 2006, 6:3294-3305.

14. Crapoulet N, Robineau S, Raoult D, Renesto P: Intervening sequence acquired by lateral gene transfer in Tropheryma whipplei results in 23S rRNA fragmentation. Appl Environ Microbiol 2005, 7I:6698-670I.

15. Crapoulet N, Barbry P, Raoult D, Renesto P: Global transcriptome analysis of Tropheryma whipplei in response to temperature stresses. J Bacteriol 2006, 188:5228-5239.

16. La MV, Barbry P, Raoult D, Renesto P: Molecular basis of Tropheryma whipplei doxycycline susceptibility examined by transcriptional profiling. J Antimicrob Chemother 2007, 59:370-377.

17. Murray AE, Lies D, Li G, Nealson K, Zhou J, Tiedje JM: DNA/DNA hybridization to microarrays reveals gene-specific differences between closely related microbial genomes. Proc Natl Acad Sci U S A 2001, 98:9853-9858.

18. Schoolnik GK: Functional and comparative genomics of pathogenic bacteria. Curr Opin Microbiol 2002, 5:20-26.

19. Mongodin EF, Hance IR, Deboy RT, Gill SR, Daugherty S, Huber R, Fraser CM, Stetter K, Nelson KE: Gene transfer and genome plasticity in Thermotoga maritima, a model hyperthermophilic species. J Bacteriol 2005, 187:4935-4944.

20. Hinchliffe SJ, Isherwood KE, Stabler RA, Prentice MB, Rakin A, Nichols RA, Oyston PC, Hinds J, Titball RW, Wren BW: Application of DNA microarrays to study the evolutionary genomics 
of Yersinia pestis and Yersinia pseudotuberculosis. Genome Res 2003, I3:2018-2029.

21. Zhou D, Han Y, Song Y, Tong Z, Wang J, Guo Z, Pei D, Pang X, Zhai J, Li M, Cui B, Qi Z, Jin L, Dai R, Du Z, Bao J, Zhang X, Yu J, Wang J, Huang $P$, Yang R: DNA microarray analysis of genome dynamics in Yersinia pestis: insights into bacterial genome microevolution and niche adaptation. J Bacteriol 2004, I 86:5 I 38-5 I 46

22. Brunelle BW, Nicholson TL, Stephens RS: Microarray-based genomic surveying of gene polymorphisms in Chlamydia trachomatis. Genome Biol 2004, 5:R42.

23. Behr MA, Wilson MA, Gill WP, Salamon H, Schoolnik GK, Rane S, Small PM: Comparative genomics of BCG vaccines by wholegenome DNA microarray. Science 1999, 284: 1520-1523.

24. Ge H, Chuang YY, Zhao S, Tong M, Tsai MH, Temenak JJ, Richards AL, Ching WM: Comparative genomics of Rickettsia prowazekii Madrid E and Breinl strains. J Bacteriol 2004, I 86:556-565.

25. Stabler RA, Marsden GL, Witney AA, Li Y, Bentley SD, Tang CM, Hinds J: Identification of pathogen-specific genes through microarray analysis of pathogenic and commensal Neisseria species. Microbiology 2005, I 5 I:2907-2922.

26. Hotopp JC, Grifantini R, Kumar N, Tzeng YL, Fouts D, Frigimelica E, Draghi M, Giuliani MM, Rappuoli R, Stephens DS, Grandi G, Tettelin $\mathrm{H}$ : Comparative genomics of Neisseria meningitidis: core genome, islands of horizontal transfer and pathogen-specific genes. Microbiology 2006, I 52:3733-3749.

27. Peng J, Zhang X, Yang J, Wang J, Yang E, Bin W, Wei C, Sun M, Jin $Q$ The use of comparative genomic hybridization to characterize genome dynamics and diversity among the serotypes of Shigella. BMC Genomics 2006, 7:218.

28. Beare PA, Samuel JE, Howe D, Virtaneva K, Porcella SF, Heinzen RA: Genetic diversity of the $Q$ fever agent, Coxiella burnetii, assessed by microarray-based whole-genome comparisons. Bacteriol 2006, I 88:2309-2324.

29. Yang HL, Zhu YZ, Qin JH, He P, jiang XC, Zhao GP, Guo XK: In silico and microarray-based genomic approaches to identifying potential vaccine candidates against Leptospira interrogans. BMC Genomics 2006, 7:293.

30. Kim CC, Joyce EA, Chan K, Falkow S: Improved analytical methods for microarray-based genome-composition analysis. Genome Biol 2002, 3:RESEARCH0065.

31. Fukiya S, Mizoguchi H, Tobe T, Mori H: Extensive genomic diversity in pathogenic Escherichia coli and Shigella Strains revealed by comparative genomic hybridization microarray. J Bacteriol 2004, 186:39| I-392।.

32. Koide T, Zaini PA, Moreira LM, Vencio RZ, Matsukuma AY, Durham AM, Teixeira DC, El-Dorry H, Monteiro PB, da Silva AC, VerjovskiAlmeida S, da Silva AM, Gomes SL: DNA microarray-based genome comparison of a pathogenic and a nonpathogenic strain of Xylella fastidiosa delineates genes important for bacterial virulence. J Bacteriol 2004, 186:5442-5449.

33. Broekhuijsen M, Larsson P, Johansson A, Bystrom M, Eriksson U, Larsson E, Prior RG, Sjostedt A, Titball RW, Forsman M: Genomewide DNA microarray analysis of Francisella tularensis strains demonstrates extensive genetic conservation within the species but identifies regions that are unique to the highly virulent $\mathbf{F}$. tularensis subsp. tularensis. J Clin Microbiol 2003, 41:2924-2931.

34. Andersson SG, Zomorodipour A, Andersson JO, Sicheritz-Ponten T Alsmark UC, Podowski RM, Naslund AK, Eriksson AS, Winkler HH, Kurland CG: The genome sequence of Rickettsia prowazekii and the origin of mitochondria. Nature 1998, 396:I33-I40.

35. Stephens RS, Kalman S, Lammel C, Fan J, Marathe R, Aravind L, Mitchell W, Olinger L, Tatusov RL, Zhao Q, Koonin EV, Davis RW: Genome sequence of an obligate intracellular pathogen of humans: Chlamydia trachomatis. Science 1998, 282:754-759.

36. Seshadri R, Paulsen IT, Eisen JA, Read TD, Nelson KE, Nelson WC Ward NL, Tettelin H, Davidsen TM, Beanan MJ, Deboy RT, Daugherty SC, Brinkac LM, Madupu R, Dodson RJ, Khouri HM, Lee KH, Carty HA, Scanlan D, Heinzen RA, Thompson HA, Samuel JE, Fraser CM, Heidelberg JF: Complete genome sequence of the Q-fever pathogen Coxiella burnetii. Proc Natl Acad Sci U S A 2003, 100:5455-5460.

37. Larsson $P$, Oyston PC, Chain $P$, Chu MC, Duffield M, Fuxelius HH, Garcia E, Halltorp G, Johansson D, Isherwood KE, Karp PD, Larsson E, Liu Y, Michell S, Prior J, Prior R, Malfatti S, Sjostedt A, Svensson K, Thompson N, Vergez L, Wagg JK, Wren BW, Lindler LE, Andersson
SG, Forsman M, Titball RW: The complete genome sequence of Francisella tularensis, the causative agent of tularemia. Nat Genet 2005, 37: 153-159.

38. Andersson JO, Andersson SG: Insights into the evolutionary process of genome degradation. Curr Opin Genet Dev 1999, 9:664-67I.

39. Ochman H, Moran NA: Genes lost and genes found: evolution of bacterial pathogenesis and symbiosis. Science 200I, 292:1096-1099.

40. Chan K, Baker S, Kim CC, Detweiler CS, Dougan G, Falkow S: Genomic comparison of Salmonella enterica serovars and Salmonella bongori by use of an S. enterica serovar typhimurium DNA microarray. J Bacteriol 2003, 185:553-563.

41. Dorrell N, Mangan JA, Laing KG, Hinds J, Linton D, Al-Ghusein H, Barrell BG, Parkhill J, Stoker NG, Karlyshev AV, Butcher PD, Wren BW: Whole genome comparison of Campylobacter jejuni human isolates using a low-cost microarray reveals extensive genetic diversity. Genome Res 200I, I I:I706-17I5.

42. Salama N, Guillemin K, McDaniel TK, Sherlock G, Tompkins L, Falkow S: A whole-genome microarray reveals genetic diversity among Helicobacter pylori strains. Proc Natl Acad Sci U S A 2000, 97:| 14668-| 4673 .

43. Aakra A, Nyquist OL, Snipen L, Reiersen TS, Nes IF: A survey of genomic diversity in Enterococcus faecalis by microarray based comparative genomic hybridization. Appl Environ Microbiol 2007, 73:2207-2217.

44. Reddy M: Role of FtsEX in cell division of Escherichia coli: viability of ftsEX mutants is dependent on functional Sufl or high osmotic strength. J Bacteriol 2007, 189:98-108.

45. De Leeuw E, Graham B, Phillips GJ, ten Hagen-Jongman CM, Oudega $B$, Luirink J: Molecular characterization of Escherichia coli FtsE and FtsX. Mol Microbiol 1999, 31:983-993.

46. Merino S, Altarriba M, Gavin R, Izquierdo L, Tomas JM: The cell division genes (ftsE and $X$ ) of Aeromonas hydrophila and their relationship with opsonophagocytosis. FEMS Microbiol Lett 200I, 198:183-188

47. Alsmark CM, Frank AC, Karlberg EO, Legault BA, Ardell DH, Canback B, Eriksson AS, Naslund AK, Handley SA, Huvet M, La SB, Holmberg $M$, Andersson SG: The louse-borne human pathogen Bartonella quintana is a genomic derivative of the zoonotic agent Bartonella henselae. Proc Natl Acad Sci U S A 2004, I01:97|6-972I.

48. alignment NPS@: CLUSTALW multiple alignment. 2007 [http:/ Inpsa-pbil.ibcp.fr/cgi-bin/npsa automat.pl?page=/NPSA/ npsa clustalwan.html].

49. Sturn A, Quackenbush J, Trajanoski Z: Genesis: cluster analysis of microarray data. Bioinformatics 2002, 18:207-208.

50. database GEO database: . 2007 [http://www.ncbi.nlm.nih.gov/geo/].

51. Viewer TIGRM Multiexperiment Viewer: . 2007 [http:// www.tm4.org/mev.html].

Publish with Bio Med Central and every scientist can read your work free of charge

"BioMed Central will be the most significant development for disseminating the results of biomedical research in our lifetime. "

Sir Paul Nurse, Cancer Research UK

Your research papers will be:

- available free of charge to the entire biomedical community

- peer reviewed and published immediately upon acceptance

- cited in PubMed and archived on PubMed Central

- yours - you keep the copyright

Submit your manuscript here:

http://www.biomedcentral.com/info/publishing_adv.asp
BioMedcentral 